\title{
The Impact of Islamic Banks and Takaful Companies on Economic Growth: A Case of Pakistan
}

\author{
Amna Sohail Rawat * $\quad$ Syed Kumail Mehdi ${ }^{\dagger}$
}

\begin{abstract}
The purpose of this study is to examine the impact of Islamic Banks and Takaful on economic growth of Pakistan. Using panel data from 2009 to 2014 of five Islamic Banks and five Takaful Companies, and taking Gross Domestic Product (GDP) as dependent variable, Total Deposits (TD) of Islamic Banks and Total contribution (TC) of Takaful companies as independent variables, analysis is done to find the impact of Islamic Banks and Takaful companies on the economic growth of the country. The study employs Fixed Effect Model for the econometric analysis. The study concluded that there is a significant role of Total Deposits of Islamic Banks and Total Contributions of the Takaful Companies in the growth of the economy. It is thus, recommended that Economic policymakers should take into account this valuable fact and should take serious measures for facilitating Islamic Financial Sector. This research can be used as a platform for the economic policymakers to evaluate and comprehend the importance of Islamic Financial System in developing countries like Pakistan.
\end{abstract}

Keywords: Islamic banks, Takaful companies, economic growth, panel data, regression analysis.

\section{Introduction}

Islamic finance has developed as a form of financial intermediation for the sake of conducting financial transactions that ensure the principles of Islamic finance to be followed strictly. To become a truly viable and competitive alternative to conventional financial systems at the global level, islamic banking and finance industry has been making breakthrough improvements. It has also gained mass acceptance and appreciation among Muslim countries (Khan \& Bhatti, 2008).

Islamic financing is among growing segments of the global financial industry, and, because of this very reason, the vitality of Islamic Financial Sector cannot be ignored. There are some considerable factors that have contributed towards the solid growth of Islamic financial sector, such as need of many Islamic countries for Shari'ah compliant products, strengthening the development of the financial sector as per the Islamic laws, growing demand of Shari'ah compliant financial products in Muslim communities, and the concept of profit and loss sharing.

\footnotetext{
* Research Associate, Department of Business Administration, IQRA University, Karachi (75300), Pakistan. E-mail: amna.sohail@iqra.edu.pk.

†Business Graduate, Department of Business Administration, IQRA University, Karachi (75300), Pakistan.
} 
Islamic Banking and Takaful have features that positively contribute towards the economic growth (Haiss \& Sumegi, 2008; Lee, 2011; Asif, Ather, \& Isma, 2014; M. S. A. Majid, 2008; Muye \& Hassan, 2016). Islamic financial transactions certainly promote a strong relationship between the financial and real economy sector due to its participatory nature and risk sharing approach. Transactions of Islamic finance are in line with the Islamic Jurisprudence prohibitions of Riba (Interest), Gharar (Uncertainty) and Maysir (Gambling) which reduces the financial instability of the overall financial system and economy.

The system of Islamic banking that strictly follows the Islamic Jurisprudence rules and regulation, has been noticed on a growing track in the recent years as shown in Figure 1. It has demonstrated itself as a reasonable alternative to the present conventional system of banking.

Figure 1

Total Deposits of Islamic Banks

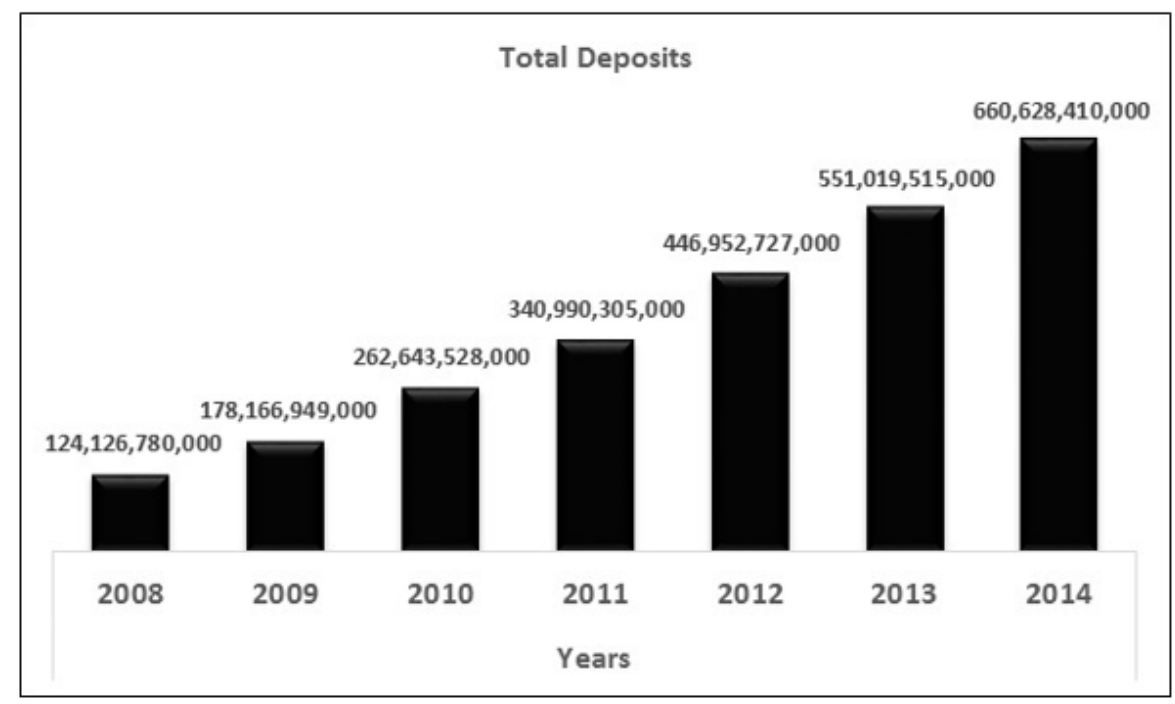

Source: Islamic Banks, Annual Reports, (2008-2014)

Islamic banking sector of Pakistan has been growing under the dual banking system. Back in 1993, the idea of "Islamic Banking Window" got announced and permitted the interested conventional banks to adopt the Islamic banking products while using their current banking infrastructure. This concept received high appreciation and acceptance by the conventional banks as they became able to expand their existing reputation, infrastructure and to grab new market segments. Through this idea, investors got the opportunity either to opt for Islamic or Conventional banking products. Just because of this great idea, approximately 17 conventional banks have been operating their Islamic window and branches in Pakistan ${ }^{1}$.

\footnotetext{
${ }^{1}$ State Bank of Pakistan (2012)
} 
Table 1

No. of Islamic Banks' Branches and Windows operating in Pakistan

\begin{tabular}{lcccccc}
\hline Detail & \multicolumn{2}{c}{$\begin{array}{c}\text { Islamic Banking Bulletin } \\
\text { Sep-15 }\end{array}$} & $\begin{array}{c}\text { Islamic Banking Bulletin } \\
\text { Sep-12 }\end{array}$ & Increase & Increase \\
& $\begin{array}{c}\text { No. of } \\
\text { Branches }\end{array}$ & $\begin{array}{c}\text { No. of } \\
\text { Windows }\end{array}$ & $\begin{array}{c}\text { No. of } \\
\text { Branches }\end{array}$ & $\begin{array}{c}\text { No. of } \\
\text { Windows }\end{array}$ & $\begin{array}{c}\text { No. of } \\
\text { Branches }\end{array}$ & $\begin{array}{c}\text { No. of } \\
\text { Windows }\end{array}$ \\
\hline Full-Fledge Islamic Banks & 986 & - & 604 & - & 382 & - \\
Islamic Branches of Conventional Banks & 681 & 1,013 & 322 & - & 359 & 1,013 \\
Sub Branches & 116 & - & 51 & - & 65 & - \\
Total & 1,783 & 1,013 & 977 & - & 806 & 1,013 \\
\hline Source: Banking Policy \& Regulations Department, State
\end{tabular}

Source: Banking Policy \& Regulations Department, State Bank of Pakistan.

Pakistan's insurance sector is comparatively small. In 2012, notification Takaful rules 2012 were issued by Security Exchange Commission of Pakistan in which they allowed conventional insurance companies to operate Takaful windows with their existing conventional insurance infrastructure for boosting sector's market share and increasing competition ${ }^{2}$.

From 2008 onwards Takaful industry is growing in Pakistan. While focusing on the Muslim population growing percentage, different efforts are made to promote Takaful business and introducing innovative Takaful products to fulfill the needs of the customers. Although there is a rising competition in the insurance market, the Takaful operators' performance and achievements are appreciable.

Figure 2

Total contributions of Takaful Companies

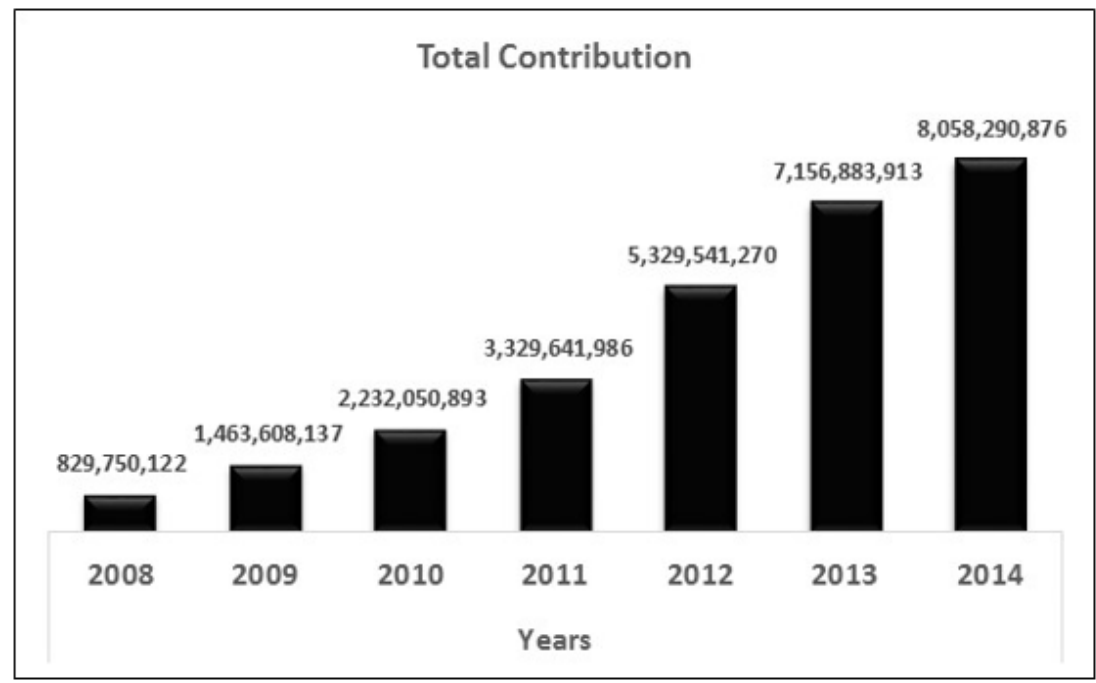

Source: Takaful companies, Annual Reports, (2008-2014)

With the speedy development of the Islamic financial sector particularly in the field of Islamic Banking and Takaful base sector, substantial growth and development has been

\footnotetext{
${ }^{2}$ SECP (2012)
} 
noticed. Total Deposits of five full-fledged Islamic bank was 1,184 million US\$ in 2008 and in 2014 it was 6,306 million US\$, further Total Contribution of five full-fledged Takaful companies was 7 million US\$ in 2008 and in 2014 it was 76 million US\$.

The growth in the Islamic Financial sector calls for an intensive research on the following idea so that the unanswered questions can be answered and the ambiguities in the minds of potential investors can be removed. Islamic Banking has characteristics that contribute positively towards the economic growth (Abduh \& Chowdhury, 2012; Abduh, Brahim, \& Omar, 2012; M. S. Majid \& Kassim, 2015), as well as Insurance also has positive contribution to the economic growth of the country (Haiss \& Sumegi, 2008; Lee, 2011; Muye \& Hassan, 2016). Existing literature on the considerate topic consist of studies that have either discussed about the impact of Islamic banking on economic growth or about the impact of Islamic Insurance (Takaful) on economic growth. To the best of our knowledge, no study has encountered the impact of both the Islamic banking and takaful industry on the economic growth of Pakistan together. This study is conducted to fulfill this gap and identify the overall impact of Islamic banking and takaful on economic growth in case of Pakistan. Economic growth is represented by Gross Domestic Product particularly in Pakistan scenario because GDP is considered a pillar of the state as stronger the economy the stronger the country and impact of Islamic industry are denoted by as a proxy of Total Deposits and Total Contribution. Further Inflation, Population Growth, Foreign Direct Investment and Interest Rate are taken as control variables.

This study is helpful for Islamic industry players to take a better future decision, concerning Islamic industry enhancement that will lead to economic growth.

The rest of the study is organized as follows. The next part of the study sketches the review of the past studies that have been up taken on the same topic. It is then followed by a description of the data and methodology employed in the study. After a brief discussion of the methodology, the econometric estimations are highlighted. The study is concluded with a discussion on the results and closing remarks.

\section{Literature Review}

A number of past studies have been conducted to measure the role of financial intermediaries in the economic growth of the countries. Haiss and Sumegi (2008) investigated the relationship between insurance and economic growth in Europe using cross country panel data set for the duration 1992 to 2005; Chen, Lee, and Lee (2012) identified the link between growth of life insurance market and economic growth by utilizing the panel data of 60 countries from the year 1976 to 2005; Lee (2011) determined the impact of insurance market on economic growth for some OECD economies using the data set of life insurance premium and non-life insurance premium for the period of 1979 to 2006; Phutkaradze (2014) investigated the impact of insurance market on the economic growth in post-transition countries over the period of 2000 to 2012. All of the mentioned studies found that there is a positive impact of the insurance industry on the growth of the economy.

Further Kugler and Ofoghi (2005) investigated the long run relationship and causality 
between economic growth and insurance market volume for the United Kingdom, using the time series data from 1966 to 2003. The authors found the evidence of long-run relationship between insurance market's development and economic growth. Arena (2008) also depicted a relationship between insurance market activities and economic growth. Beck and Levine (2004) identified the contribution of financial sector development using the data of 40 countries over the duration of 1976 to 1998 and concluded that financial development is having a positive role in economic growth. However, Adams, Andersson, Andersson, and Lindmark (2005) found a contrasting evidence, they identified the historical relation among insurance, banking and economic growth particularly in Sweden by utilizing time series data set from 1830 to 1998 of real GDP, insurance penetration (Total annual premium per capita), and bank credit (Total real bank lending to non-bank public). Their findings predicted that development of domestic banking leads to economic growth but insurance does not lead to economic growth in Sweden.

In Pakistan, the Muslim population is in majority and they have a valid reason to express their interest in developing Islamic financial industry. As Muslims are aware of the drawbacks of interest based financial system, so, they are supposed to react positively to promote Islamic financial system. According to Hasan and Dridi (2010), Islamic legal structure in finance and banking increases the performance of the economic activity. A similar kind of finding was presented Fadzlan (2007), who proposed that both Muslim and Non-Muslim populations in Malaysia appreciate Islamic banking system because it is an effective alternative of conventional financial intermediation. Asif et al. (2014) investigated the trend of Islamic investment in Pakistan's economic growth by using the data set from 2002 to 2012. They used Advances of scheduled bank (ADV) as the dependent variable to represent economic growth and Islamic Banks' Deposits, Inflation, Interest Rate and FDI were taken as the independent variables. They found that deposits of Islamic banks have a significant and positive impact on the economic growth and concluded that Islamic financial system plays a pivotal role in enhancing economic growth by mobilizing deposits and providing finance. They further proposed that Islamic Banking System is considered as the backbone of Islamic financial system.

Another important study in this regard is of (Muye \& Hassan, 2016). The study identified that there is robust positive and significant impact of Islamic insurance activities on economic growth by using panel data set of 22 countries from the period of 2004 to 2012 . M. S. A. Majid (2008), on the other hand, examined the role of Islamic Banking on economic growth in Malaysia by using a time series dataset from the year 1997 to 2009 and discovered a significant role of Islamic banking contribution on economic growth. According to them, total deposits are considered as Islamic financial indicator and plays an important role in explaining the variations of the economic growth. A similar kind of study was conducted by Abduh and Chowdhury (2012) who examined that whether Islamic banking matters for economic development in Bangladesh and concluded that Islamic bank financing has a significant and positive relationship with economic growth. Following the same pattern, Abduh et al. (2012) investigated the short-term and long-run relationship between Islamic financial development and Conventional financial development with the economic growth in Bahrain. Their study discovered the evidence that Islamic and conventional financial development have a significant and positive correlation with the economic growth in long 
run.

However, According to Hachicha and Ben Amar (2015), Islamic banks' development on economic growth stays confusing both at theoretical and empirical levels. Indonesian industrial analysis on Islamic banking has discovered some facts regarding the contribution of Islamic banking towards economic development. Findings have stated that Islamic banking does not significantly contribute to the long-term economic development because liquid deposits on the liability side matter for getting the potential of short-term liquidity withdrawals from depositors. Due to this fact, Islamic banks invest most of the funds in the short term financing to cope up with the short term demand for liquidity and earn the regular and positive income from short-term debt.

Total insurance premium (contribution) is paid for risk transfer. Insurance basically functions as a shock absorber for any unforeseen event. The insuree pays a premium to save himself from the specific risk that is evaluated in the term of the insurance premium paid relative to GDP (Haiss \& Sumegi, 2008). Catalan, Impavido, and Musalem (2000) also proposed that impact of insurance industry can be tested as a provider of protection from risk.

\section{Data and Methodology}

In this study, a panel dataset is constructed of five complete Islamic banks of Pakistan i.e. Meezan Bank, Al Baraka Bank Pakistan Limited, Bank Islami, Dubai Islamic Bank Pakistan Limited, and Burj Bank and Takaful companies i.e., Pak-Kuwait Takaful Company Limited, Takaful Pakistan Limited, Pak-Qatar General Takaful, Pak-Qatar Family Takaful and Dawood Family Takaful Limited for the period 2009 to 2014. To ensure the robustness of the data, several data sources were used. The data is accumulated from Islamic banks and Takaful companies' annual financial reports, World Development Indicators (WDI) website, State Bank of Pakistan's website and Economic Survey of Pakistan.

The study has considered six variables that are Gross Domestic Product, Total Contribution, Total Deposits, Inflation, Foreign Direct Investment and Interest Rate. To ensure the normality of the data, log of every variable has been generated. The description of the variables is below.

\section{Dependent Variable}

\section{Gross Domestic Product (GDP)}

In this study, GDP is used to represent the economic growth. GDP growth shows the overall progress of the country and provides the widest quantitative measures of the country's total economic activity. 


\section{Independent Variables}

\section{Total Contribution (TC)}

Takaful Contribution is also known as Ra'sul Mal. Takaful operator receives the payment of Takaful installment or Takaful contributions (premium) from the policyholder/Takaful participant.

\section{Total Deposits (TD)}

Deposits contain money which is placed into a banking institution for the sake of safe keeping. Deposit is a liability that is owned by the bank against the depositor.

\section{Control Variables}

\section{Inflation (INF)}

Inflation is a continued/sustained rising in the general price of the services and goods in an economy during a certain period of time and generally, it is measured by consumer price index.

\section{Foreign Direct Investment (FDI)}

It is an investment in another country (host country) by a company or individual due to business interest for business operations or obtaining business assets in the host country. FDI net inflows are taken is this study.

\section{Interest Rate (INT)}

In this study, the Karachi Interbank Offered Rate (KIBOR) is taken as a proxy of Interest Rate. It is an average rate of interest at which term deposits (TD) are offered among prime banks in interbank market or wholesale money market of Pakistan.

\section{Econometric Estimation}

To gauge the impact of Islamic Financial intermediaries on economic growth of the country, we used panel data consisting of $n$ cross sections where $n=1, \ldots, N$ and observed at $t$ time intervals where $\mathrm{t}=1, \ldots, \mathrm{T}$, and hence, a panel data set is generated for the study with $\mathrm{n} \mathrm{x} \mathrm{t}$ observations. Following the basic specification suggested by Brooks (2014), the elementary model followed for the study is,

$$
y_{n t}=\alpha_{o}+\beta x_{n t}+\epsilon_{n t}
$$

Where, $y$ is the dependent variable i.e. Gross Domestic Product in our case and $\alpha_{o}$ is the intercept term, $\beta$ represents the regression coefficient and $x$ are the set of independent variables i.e. Total Contribution and Total Deposits in our case. Since we are interested in analyzing the impact of Islamic Banks and Takaful Companies on the economic growth of the country, therefore, the econometric models under consideration can be stated as, 
Model 1 (Islamic Banks)

$$
L N G D P=\alpha+\beta_{1} L N T D+\beta_{2} L N I N F+\beta_{3} L N F D I+\beta_{4} L N I N T+\epsilon_{t}
$$

\section{Model 2 (Takaful Companies)}

$$
L N G D P=\alpha+\beta_{1} L N T C+\beta_{2} L N I N F+\beta_{3} L N F D I+\beta_{4} L N I N T+\epsilon_{t}
$$

Where; GDP $=$ Gross Domestic product, $\mathrm{TC}=$ Total Contribution, $\mathrm{TD}=$ Total Deposits, INF $=$ Inflation, FDI $=$ Foreign Direct Investment, INT $=$ Interest Rate and $\epsilon \tau=$ Error Term.

\section{Results}

\section{Descriptive Statistics}

Descriptive statistics are used to represent the basic structure of the data. Its purpose is to provide simple summaries about the data and the sample and helps in recognizing the emerging pattern in the data. The given table 2 represents the descriptive statistics of the variables.

Table 2

\begin{tabular}{lcccccc}
\multicolumn{2}{l}{ Descriptive Statistics } & \multicolumn{7}{l}{$l$} \\
\hline LNTC & LNTD & LNGDP & LNFDI & LNINF & LNINT \\
Median & 20.09016 & 24.73126 & 20.80481 & 21.14768 & 2.353515 & 2.438192 \\
Maximum & 20.08704 & 24.76945 & 20.81081 & 21.15473 & 2.193613 & 2.431157 \\
Minimum & 22.34793 & 26.66455 & 20.86087 & 21.57256 & 3.028515 & 2.647592 \\
Observations & 17.72399 & 22.63794 & 20.75682 & 20.57128 & 1.786508 & 2.277267 \\
& 30 & 30 & 30 & 30 & 30 & 30 \\
\hline
\end{tabular}

\section{Correlation Matrix}

The given Table- 3 and 4 represent the correlation matrix of the independent variables used in multivariate regression analysis to check the multicollinearity, if any, among the variables. The literature suggests that if the degree of correlation among the variables is not greater than 0.8 then, the problem of multicollinearity does not exist in the data (Ali, 2015). In our case, as depicted in Table 3 and 4, all correlation coefficients are smaller than 0.8 and hence problem of multicollinearity doesn't exist in our data.

\section{Regression Results}

To evaluate that which is the most appropriate model between fixed effect and random effect models, we have employed Hausman test (Greene, 2000). If the null hypothesis of the test (i.e. Country effects are not correlated with the regressors) is not accepted, then fixed effect model is appropriate. The results of the Hausman test indicated that null hypothesis is not accepted and fixed effect model is appropriate for our study. The results estimated from the fixed effect model are listed in the given table 5 below. 
Table 3

Correlation Matrix of Model 1

\begin{tabular}{ccccc}
\hline & LNTC & LNFDI & LNINT & LNINF \\
\hline LNTC & 1.000000 & & & \\
LNFDI & -0.288377 & 1.000000 & & \\
LNINT & -0.436894 & 0.645103 & 1.000000 & \\
LNINF & -0.420389 & 0.549857 & 0.743324 & 1.000000 \\
\hline Source: Authors' Estimation & & &
\end{tabular}

Table 4

Correlation Matrix of Model 2

\begin{tabular}{lcccc}
\hline & LNTD & LNFDI & LNINF & LNINT \\
\hline LNTD & 1.000000 & & & \\
LNFDI & -0.326757 & 1.000000 & & \\
LNINF & -0.419382 & 0.549857 & 1.000000 & \\
LNINT & -0.428175 & 0.645103 & 0.743324 & 1.000000 \\
\hline
\end{tabular}

Source: Authors' Estimation

Table 5

Regression Results

\begin{tabular}{lcccccc}
\hline Determinants & \multicolumn{3}{c}{$\begin{array}{c}\text { Model 1 } \\
\text { Islamic Banks }\end{array}$} & \multicolumn{3}{c}{$\begin{array}{c}\text { Model 2 } \\
\text { Takaful Companies }\end{array}$} \\
& Coefficient & Std.error & P-value & Coefficient & Std.error & P-value \\
\hline Constant & 4.757 & 2.0598 & $0.0312^{* *}$ & 21.203 & 0.3098 & $0.000^{* * *}$ \\
Total Deposits & 0.162 & 0.0707 & $0.0325^{* *}$ & - & - & - \\
Total Contributions & - & - & - & 0.0152 & 0.0052 & $0.0098^{* * *}$ \\
Foreign Direct Investment & -0.040 & 0.1101 & $0.0012^{* * *}$ & -0.0317 & 0.0169 & $0.0766^{*}$ \\
Interest Rate & -3.395 & 0.2665 & $0.0000^{* * *}$ & 0.0506 & 0.0529 & 0.3516 \\
Inflation & 0.044 & 0.0130 & $0.0024^{* * *}$ & 0.0399 & 0.0132 & $0.0075^{* * *}$ \\
Adjusted $R^{2}$ & & 0.9085 & & & 0.7453 & \\
F-Statistics & & 37.005 & & & 0.5841 & $(0.000)^{* * *}$ \\
(P-Value) & & $(0.000)^{* * *}$ & & & &
\end{tabular}

The results of the assessed relationship among variables have been stated above. Total deposits of Islamic banks are found positively related with the economic growth of the country. These findings are in line with the empirical findings of Asif et al. (2014). Total contributions of Takaful companies were also found to be positively associated with the GDP of the country, this finding is also supported by various past studies like that of Haiss and Sumegi (2008); Chen et al. (2012); Lee (2011); Phutkaradze (2014), all of these studies found a significant positive association between insurance industry and economic growth. Inflation is estimated to be positively associated with the income of the economy. This finding is supported by Mallik and Chowdhury (2001); Hussain and Malik (2011), who have also reported a significant positive link between these variables in their study. FDI is found to be negatively linked with the growth of the economy which is also an empirically tested fact in the literature as reported by (Quazi, 2004; Eller, Haiss, \& Steiner, 2005; K. Rahman, 2008; A. Rahman, 2015).

Interestingly, both of the models are representing contrasting view when we observe the results of interest rate. The interest rate is found to be significant and negative in the first model. This evidence is in accordance with Abel, Bernanke, and Croushore (2012); Akinlo 
and Apanisile (2014). However, the second model reported interest rate to be insignificant for economic growth, this result finds it support from Asif et al. (2014).

\section{Discussion}

The aim of this study was to analyze the impact of Islamic banks and takaful companies on Pakistan's economy. To serve the purpose, data were gathered for the period of 2009 to 2014. GDP was taken as the dependent variable and Total Deposits, Total Contribution are considered as independent variables. Others variables such as Interest Rate, Inflation, and Foreign Direct Investment were taken as control variables.

This research provides a platform to economic policymakers to analyze and comprehend the vitality of Islamic Financial System for a developing country like Pakistan. It can also provide a basis to the economic legislators to look for the means of implementing Islamic financial system more successfully in the economy so that the ambiguities regarding Islamic financial system can be removed. It may bring a positive change in economic activities of the country, and consequently will increase economic growth (Asif et al., 2014). The relationships of the variables might seem out of the norm, however, the data paints a picture that economics for a developing country differs from the developed ones. The obstacles faced by the developing countries and the impact of these hiccups vary for developed and developing countries.

The study gave conclusive evidence that total deposits for Islamic Banks and total contribution for Takaful have little, although significant impact on the economic condition of the country. The results implies that the development of Islamic financial system is a policy that should be considered by the government in order to increase the income of the economy. For a country like Pakistan, where Muslims constitute the major part of population, people have a strong reason to react positively towards Islamic financial system. The Islamic Financial Sector is growing but it is in its initial phase. People have started taking keen interest in it as Muslims are cognizant of the impairments of the interest-based financial system as per the tenets of Islam. Hence, they are anticipated to react positively towards promotion of Islamic Financial System. The advent of Islamic finance should be observed in the given perspective. Islamic finance is a part of Islamic economics. It has the prospective to add intensively towards the accomplishment of the key social and economic goals of fairness and rightful dissemination of resources (Chapra, 1985), and consequently, it can boost the economic growth. The foundation of Islamic banking and other financial intermediation institutions is not merely an effort to accomplish Islamic culture's longing to have a "legal" (halal) system of financial services in a strict legalistic manner to get away from the forbidden (haram) features of conventional financial services. But, the idea is to provide the Muslim society with an effective financial intermediation that can provide them the financial security as provided by the conventional financial system. It is the right of the Muslim society to presume a greater level of corporate social responsibility from Islamic financial institutions as they carry the "Islamic" name, which imparts a responsibility for them that they should promote Islamic ideals and objectives in human life (Dusuki \& Abdullah, 2007; Sairaly, 2011). 
Two of our control variables i.e., Inflation and Foreign Direct Investment play a noteworthy part in the economic growth of Pakistan. FDI plays a detrimental role in the economic growth and has a negative impact on the economy. It causes money or assets to swiftly flow out from the country due to economic moment, causing an opposing impact on the host country. It may also cause crowding out of domestic capital and a rise in the imports of the host country, as, Foreign Investment' companies usually need high technology machinery and intermediate goods that may not be available in the host country (A. Rahman, 2015; Quazi, 2004; Eller et al., 2005; K. Rahman, 2008). As far as inflation is concerned, it can be a help for a developing economy in times of low economic growth. When the economy is not running at it potential ability, meaning that there is idle labor or resources, inflation theoretically aids in growing output. By increasing the money supply, the spending in the economy is increased, which in turn, increases the aggregate demand. More demand, in turn, triggers more production to fulfill that demand and brings in economic growth. Mallik and Chowdhury (2001) also found a long run positive association between inflation and economic growth for four South Asian economies and concluded that moderate inflation rates can foster economic growth.

A rise in the rate of interest may reduce the output of the economy as it reduces the tendency of the businesses to borrow from the financial institutions, where else, in an Islamic setting, interest can also serve as an insignificant component for economic growth. Because of the religious restriction people do not care much about the change of interest rate while making deposits in Islamic financial institutions (Mushtaq \& Siddiqui, 2016). It may also serve as an insignificant component for economic growth because of its distortion. The state bank announces a uniform interest rate for all sectors of the economy, but practically, interest rate changes from sector to sector, that causes distortion (Asif et al., 2014).

\section{Conclusion and Policy Implications}

The continuous growth of Islamic financial industry and the rising interest of the contributors in this industry needs a deeper analysis of the Islamic financial contribution in the economy. Information regarding relevancy and significance of the Islamic Finance contribution towards country's economic growth can help Islamic industry players, decision makers and policy makers for setting out upcoming directions for strong expansion in this industry. The advent of Islamic financial system as a real-world financial system is often considered as appropriate in the times of a financial crunch. The counteractive resolutions that have so far been proposed for dealing with such unexpected events have not proved themselves fruitful, suspending some problems and making others eviler. The importance of Islamic finance is backed by the hope that Islamic finance could gracefully propose an articulated outlook for considering actual economic difficulties and a sincere substitute to the fundamentals of the economy and finance to attain prosperity for the general masses.

This research can be used as a platform for the fiscal legislators to evaluate and comprehend the prominence of Financial System presented by Islam in underdeveloped countries like Pakistan. The trend which is being anticipated in the development of Islamic banking and finance is that by adopting the means of Islamic Jurisprudence as the requisite 
charter for making Islamic financial contracts and as the maneuvering standard for additional expansion of the sector, it will cause the income of the economy to grow. To provide Islamic financial services a substantial presence, it is highly recommended that Shariah legal compliance should be strictly followed. This would have a definite influence on the economic substance in the form of impartial provision of resources, real economic sector progress, and crystal clear financial transactions with all the moral assurances of brotherhood, collaboration and risk sharing.

We, thus, recommend that the government should take into account the importance of this emerging financial sector as it can be of great advantage for the economy. Moreover, the institutions and entities that are offering Islamic financial services to the people should also work over the advertisement and endorsement of their services so that more awareness may be inculcated in the general masses regarding the ease of use and benefits of Islamic financial services. This would render great economic support to the economy of Pakistan.

\section{Future Recommendations}

This research can be further elaborated by taking a further closer inspection and inculcating more variables like Industrial Production Index, Price of Takaful Product, Political Instability, along with the money in circulation and population of the lowest social class. It may assist in finding a closer relationship of Islamic financial intermediaries with economic growth. Furthermore, by increasing the sample size by year can further help in getting a more in-depth answer to the research question. So it is recommended that a similar study should be up taken in which these suggestions are incorporated. 


\section{References}

Abduh, M., Brahim, S., \& Omar, M. (2012). A study on finance-growth nexus in dual financial system countries: Evidence from Bahrain. World Applied Sciences Journal, $20(8), 1166-1174$.

Abduh, M., \& Chowdhury, N. T. (2012). Does islamic banking matter for economic growth in Bangladesh? Journal of Islamic Economics, Banking and Finance, 8(3), 104-113.

Abel, A. B., Bernanke, B. S., \& Croushore, D. (2012). Macroeconomics. New Delhi: Pearson.

Adams, M., Andersson, J., Andersson, L.-F., \& Lindmark, M. (2005). The historical relation between banking, insurance and economic growth in Sweden: 1830 to 1998. Working Paper.

Akinlo, T., \& Apanisile, O. T. (2014). Relationship between insurance and economic growth in Sub-Saharan African: A panel data analysis. Modern Economy, 5(2), $120-127$.

Ali, M. (2015). Bank profitability and its determinants in Pakistan: A panel data analysis after financial crisis. Journal of Finance and Economics Research, 1(1), 1-14.

Arena, M. (2008). Does insurance market activity promote economic growth? A crosscountry study for industrialized and developing countries. World Bank Policy Research Working Paper (4098).

Asif, M., Ather, I., \& Isma, Z. (2014). Impact of islamic investment trend on economic growth- A Case Study of Pakistan. Research Journal of Management Sciences, 3(8), $8-17$.

Beck, T., \& Levine, R. (2004). Stock markets, banks, and growth: Panel evidence. Journal of Banking \& Finance, 28(3), 423-442.

Brooks, C. (2014). Introductory econometrics for finance. United Kingdom: Cambridge University Press.

Catalan, M., Impavido, G., \& Musalem, A. R. (2000). Contractual savings or stock market development, which leads? Policy Research Working Paper 2421.

Chapra, M. U. (1985). Towards a just monetary system. The Islamic Foundation, Leicester.

Chen, P.-F., Lee, C.-C., \& Lee, C.-F. (2012). How does the development of the life insurance market affect economic growth? Some international evidence. Journal of International Development, 24(7), 865-893.

Dusuki, A. W., \& Abdullah, N. I. (2007). Maqasid al-shari'ah, Maslahah and corporate social responsibility. The American Journal of Islamic Social Sciences, 24 (1), 25-45.

Eller, M., Haiss, P. R., \& Steiner, K. (2005). Foreign direct investment in the financial sector: The engine of growth for Central and Eastern Europe? Vienna University of Economics and BA, Europainstitut Working Papers, (69).

Fadzlan, S. (2007). The efficiency of islamic banking industry in Malaysia: Foreign vs domestic banks. Humanomics, 23(3), 174-192.

Greene, W. H. (2000). Econometric analysis 4th edition. New Jersey: Prentice Hall.

Hachicha, N., \& Ben Amar, A. (2015). Does Islamic bank financing contribute to economic growth? The Malaysian case. International Journal of Islamic and Middle Eastern Finance and Management, 8(3), 349-368. 
Haiss, P., \& Sumegi, K. (2008). The relationship between insurance and economic growth in Europe: A theoretical and empirical analysis. Empirica, 35(4), 405-431.

Hasan, M. M., \& Dridi, J. (2010). The effects of the global crisis on islamic and conventional banks: A comparative study. IMF Working Paper.

Hussain, S., \& Malik, S. (2011). Inflation and economic growth: Evidence from Pakistan. International Journal of Economics and Finance, 3(5), 262-276.

Khan, M. M., \& Bhatti, I. M. (2008). Islamic banking and finance: On its way to globalization. Managerial Finance, 34(10), 708-725.

Kugler, M., \& Ofoghi, R. (2005). Does insurance promote economic growth? Evidence from the UK. In Money Macro and Finance (MMF) Research Group Conference, 8.

Lee, C.-C. (2011). Does insurance matter for growth: Empirical evidence from OECD countries. The BE Journal of Macroeconomics, 11(1), 1-26.

Majid, M. S., \& Kassim, S. H. (2015). Assessing the contribution of Islamic finance to economic growth: Empirical evidence from Malaysia. Journal of Islamic Accounting and Business Research, 6(2), 292-310.

Majid, M. S. A. (2008). Does financial development matter for economic growth in Malaysia? An ARDL bound testing approach. Journal of Economic Cooperation, $29(1), 61-82$.

Mallik, G., \& Chowdhury, A. (2001). Inflation and economic growth: Evidence from four South Asian countries. Asia-Pacific Development Journal, 8(1), 123-135.

Mushtaq, S., \& Siddiqui, D. A. (2016). Effect of interest rate on economic performance: Evidence from Islamic and non-Islamic economies. Financial Innovation, 2(1). doi: 10.1186/s40854-016-0028-7

Muye, I. M., \& Hassan, A. F. S. (2016). Does islamic insurance development promote economic growth? A panel data analysis. Procedia Economics and Finance, 35, 368-373. doi: 10.1016/s2212-5671(16)00045-9

Phutkaradze, J. (2014). Impact of insurance market on economic growth in post-transition countries. International Journal of Management and Economics, 44(1), 92-105.

Quazi, R. (2004). Foreign aid and capital flight. Journal of the Asia Pacific Economy, $9(3), 370-393$.

Rahman, A. (2015). Impact of foreign direct investment on economic growth: Empirical evidence from Bangladesh. International Journal of Economics and Finance, 7(2), $178-185$.

Rahman, K. (2008). Globalization and the climate of foreign direct investment: A case for Bangladesh. Journal of Money, Investment and Banking, 5.

Sairaly, S. (2011). Best practices in socially responsible finance: Lessons for the Islamic financial industry from leading socially responsible financial institutions in the UK. Kyoto Series of Islamic Area Studies 6, Center for Islamic Area Studies at Kyoto University (KIAS), Kyoto.

SECP. (2012). Notification of Takaful Rules 2012. Securities and Exchange Commission of Pakistan. Retrieved from https://www.secp.gov.pk/document/sro-877i2012 -notification-of-takaful-rules-2012/

State Bank of Pakistan. (2012). Islamic Banking Bulletin. Retrieved from State Bank of Pakistan. Retrieved from http://www.sbp.org.pk/ibd/bulletin/bulletin.asp 